\title{
Polymorphisms of xeroderma pigmentosum genes (XPC, XPD, and XPG) and susceptibility to acute leukemia among a sample of Egyptian patients
}

\author{
Iman Rifaat EIMahgoub ${ }^{1}$ - Heba Mahmoud Gouda ${ }^{1} \cdot$ Mohamed Abdelmooti Samra $^{2}$. \\ Iman AbdelMohsen Shaheen ${ }^{1}$ - Aya Hassan EIMaraashly ${ }^{1}$
}

Received: 30 November 2016/Accepted: 22 March 2017 /Published online: 30 March 2017

(C) Springer-Verlag Berlin Heidelberg 2017

\begin{abstract}
DNA repair systems play a key role in protecting the DNA from damage caused by different endogenous and environmental factors. Genetic polymorphisms in DNA repair genes may lead to increased cancer susceptibility including leukemia. Due to different environmental genetic interactions among each population, the aim of the current study was to assess the association between three genetic polymorphisms of xeroderma pigmentosum complementation group: XPD (rs13181), XPC (rs2228001), and XPG (rs17655) and the susceptibility to acute leukemia in Egypt. The present study included 50 patients with acute leukemia, in addition to 100 normal volunteers as control group. Genotyping for the genes was done by PCR-RFLP technique. The study revealed that patients homovariant for XPD had fourfold increased risk of developing AML $(\mathrm{OR}=4.4, P=0.025)$ either alone or with variant genotypes of XPC and XPG. No statistically significant association was found between neither individual nor
\end{abstract}

Iman AbdelMohsen Shaheen

iman.shym@yahoo.com

Iman Rifaat ElMahgoub

imanelmahgoub@gmail.com

Heba Mahmoud Gouda

goudamed@hotmail.com

Mohamed Abdelmooti Samra

abdelmooti@hotmail.com

Aya Hassan ElMaraashly

ayahmaraashly@yahoo.com

1 Department of Clinical and Chemical Pathology, Faculty of Medicine, Cairo University, Cairo 11562, Egypt

2 Clinical Oncology, National Cancer Institute, Cairo University, Cairo 11562, Egypt combined polymorphisms and disease risk of ALL in this study. Determination of XPD polymorphism could be considered as molecular markers associated with susceptibility to develop AML.

Keywords Xeroderma pigmentosum complementation group · Genetic polymorphisms · Acute leukemia

\section{Introduction}

Unrepaired DNA damage can result into unregulated cell growth and cancer [1]. In order to maintain genome integrity, aberrations caused to DNA by various factors must be repaired and preserved throughout the life of a cell [2]. The nucleotide excision DNA repair (NER) is one of the major DNA repair pathways, and by which bulky adducts and wide variety of deleterious DNA lesions are removed from the genome. NER systems recognize the DNA damage, incise the DNA strand on both sides of the lesions, remove the oligonucleotide carrying the damage, and resynthetize the fragment [3].

DNA repair genes such as; xeroderma pigmentosum group D gene (XPD), also known as excision repair cross-complementing group 2 (ERCC2), xeroderma pigmentosum group $\mathrm{C}$ gene (XPC), and xeroderma pigmentosum group $\mathrm{G}$ gene (XPG or ERCC5) are implicated in the NER system. Gene polymorphisms in NER repair system may influence the individual's capacity to recognize and repair DNA lesions and thus increase cancer susceptibility including leukemia [4].

Leukemia is one of the ten most common malignancies among Arab populations, including Egypt which has intermediate incidence rate of leukemia [5]. 
As acute leukemia is a heterogeneous clonal genetic disease, with different interacting environmental and genetic causative factors among each population, the aim of the current study was to assess the association between three genetic polymorphisms of DNA repair genes: XPD (rs13181), XPC (rs2228001), and XPG (rs17655) and the susceptibility to acute leukemia in Egypt.

\section{Patients and methods}

\section{Study population}

The present study included 50 unrelated acute leukemia patients: 32 AML and 18 ALL. Patients were recruited from the outpatient clinic and the inpatient wards of National Cancer Institute, Cairo University. Acute promyelocytic leukemia (APL), double malignancy, or secondary leukemia cases were excluded. One hundred age- and sex-matched healthy volunteers, with negative consanguinity to any of the patients, were included in the study as a control group. The study was approved by the Research ethical Committee of Clinical Pathology and Medical Oncology departments, Faculty of Medicine, Cairo University, and informed consents were obtained from all participants prior to enrollment in the study.

\section{Genotyping of the candidate genes}

Total DNA was extracted from peripheral blood collected on EDTA using Gene JET Genomic DNA purification kit (Fermentas, Lithuania). Determining the polymorphisms of the studied genes was performed by polymerase chain reaction-restriction fragment length polymorphism (PCR-RFLP) method. Specific primers, supplied by Fermentas, Lithuania, and the summary of the amplification conditions are shown in Table 1. Specific restriction endonuclease enzyme for each gene (Fermentas, Lithuania) was used to digest the amplified PCR products. Ethidium bromide $2 \%$ stained agarose gel was used to detect the restricted PCR products, which were visualized using ultraviolet light. Length of the restriction fragments lengths together with the used restriction enzymes used and are shown in Table 2. Genotyping of ten randomly chosen
Table 2 Restriction enzymes and length of the restriction fragments for different polymorphisms

\begin{tabular}{llll}
\hline Polymorphism & \multirow{2}{*}{ Restriction enzyme } & Allele & Length (bp) \\
\hline XPD (rs13181) & \multirow{2}{*}{ PstI } & A/A & 290,146 \\
& & $\mathrm{~A} / \mathrm{C}$ & $290,227,146,63$ \\
& & $\mathrm{C} / \mathrm{C}$ & $227,146,63$ \\
XPC (rs2228001) & \multirow{2}{*}{ PvuII } & $\mathrm{A} / \mathrm{A}$ & 244 \\
& & $\mathrm{~A} / \mathrm{C}$ & $244,189,55$ \\
& & $\mathrm{C} / \mathrm{C}$ & 189,55 \\
XPG (rs17655) & \multirow{2}{*}{ Hin1II } & $\mathrm{C} / \mathrm{C}$ & 227,44 \\
& & $\mathrm{G} / \mathrm{C}$ & $271,227,44$ \\
& & $\mathrm{G} / \mathrm{G}$ & 271 \\
\hline
\end{tabular}

samples was repeated to ensure quality control. Samples were interpreted blindly by two different observers. Repeated results were identical to the initial results.

\section{Statistical methods}

Data were coded and entered using the statistical package SPSS version 22. Data was summarized using mean, standard deviation, median, minimum and maximum for quantitative variables and frequencies (number of cases) and relative frequencies (percentages) for categorical variables. Comparisons between quantitative variables were done using the nonparametric Mann-Whitney test. For comparing categorical data, chi-square $\left(\chi^{2}\right)$ test was performed. Exact test was used instead when the expected frequency is less than 5. Genotypic distribution of the studied SNPs in the control group was in accordance with the Hardy-Weinberg equilibrium $(P>0.05)$. Genotype and allele frequencies were compared between the disease and the control groups using chi-square tests. Odds ratio (OR) with 95\% confidence intervals was calculated. $P$ values less than 0.05 were considered as statistically significant.

\section{Results}

The main clinical and laboratory data of the acute leukemia patients are summarized in Table 3. Genotype distributions of

Table 1 Primer sequences, PCR conditions, and product size for different polymorphisms

\begin{tabular}{llll}
\hline Polymorphism & Primer sequence $\left(5^{\prime}-3^{\prime}\right)$ & PCR program & Product size (bp) \\
\hline XPD (rs13181) & F; GCC CGC TCT GGA TTA TAC G & $5^{\prime} 94^{\circ} \mathrm{C} \rightarrow 35$ & 436 \\
& R; CTA TCA TCT CCT GGC CCC C & $\left(30^{\prime \prime} 94^{\circ} \mathrm{C}+45^{\prime \prime} 57^{\circ} \mathrm{C}+45^{\prime \prime} 72{ }^{\circ} \mathrm{C}\right) \rightarrow 7^{\prime} 72{ }^{\circ} \mathrm{C}$ & \\
XPC (rs2228001) & F; GAT GCA GGA GGT GGA CTC TCT & $5^{\prime} 94^{\circ} \mathrm{C} \rightarrow 35$ & 244 \\
& R; GTA GTG GGG CAG CAG CAA CT & $\left(30^{\prime \prime} 94^{\circ} \mathrm{C}+45^{\prime \prime} 61^{\circ} \mathrm{C}+45^{\prime \prime} 72{ }^{\circ} \mathrm{C}\right) \rightarrow 7^{\prime} 72{ }^{\circ} \mathrm{C}$ & 271 \\
XPG (rs17655) & F; GAC CTG CCT CTC AGA ATC ATC & $5^{\prime} 94^{\circ} \mathrm{C} \rightarrow 35$ \\
& R; CCT CGC ACG TCT TAG TTT CC & $\left(30^{\prime \prime} 94{ }^{\circ} \mathrm{C}+45^{\prime \prime} 63{ }^{\circ} \mathrm{C}+45^{\prime \prime} 72{ }^{\circ} \mathrm{C}\right) \rightarrow 7^{\prime} 72{ }^{\circ} \mathrm{C}$ & 271 \\
\hline
\end{tabular}


Table 3 The main clinical and laboratory data of the patients

\begin{tabular}{lll}
\hline Item & AML patient group $(n=32)$ & ALL patient group $(n=18)$ \\
\hline Age $($ mean $\pm 2 \mathrm{SD})$ & $40.68 \pm 25.82$ years & $28.44 \pm 12.65$ years \\
Male & $20(62.5 \%)$ & $8(44.5 \%)$ \\
Female & $12(37.5 \%)$ & $10(55.5 \%)$ \\
Lymphadenopathy & $10(31.2 \%)$ & $12(66.7 \%)$ \\
Splenomegaly & $9(28.1 \%)$ & $14(77.8 \%)$ \\
Hepatomegaly & $12(37.5 \%)$ & $7(38.9 \%)$ \\
Hemoglobin & $8.19 \pm 2.08 \mathrm{~g} / \mathrm{dl}$ & $9.18 \pm 2.76 \mathrm{~g} / \mathrm{dl}$ \\
Total leucocytic count $($ mean $\pm 2 \mathrm{SD})$ & $58.75 \pm 63.02 \times 10^{3} / \mathrm{cm}^{3}$ & $44.67 \pm 48.27 \times 10^{3} / \mathrm{cm}^{3}$ \\
Platelets count $($ mean $\pm 2 \mathrm{SD})$ & $57.22 \pm 56.0402 \times 10^{3} / \mathrm{cm}^{3}$ & $81.46 \pm 67.17 \times 10^{3} / \mathrm{cm}^{3}$ \\
FAB classification & M0;2(6.2\%) & $\mathrm{L} 1 ; 2(11.1 \%)$ \\
& M1/M2; $13(40.6 \%)$ & $\mathrm{L} 2 ; 16(88.9 \%)$ \\
\hline
\end{tabular}

the studied polymorphisms in AML patients and controls are presented in Table 4. The patients with homozygous state of XPD SNP (rs2228001) conferred fourfold increased risk of AML $(\mathrm{OR}=4.4,95 \%$ CI 1.245-15.556), with an absolute risk increase of 0.2576 .

Dual variant genotypes of XPD gene still conferred increase risk of AML even when combined with variant XPC gene alone or when combined with both XPC and XPG variant genotypes, as it conferred two $(\mathrm{OR}=2.333,95 \% \mathrm{CI}$ 1.015-5.363) and threefold $(\mathrm{OR}=3.042,95 \%$ CI $1.179-$ 7.849) of incidence of AML, with an absolute risk increase of 0.1166 and 0.1924 , respectively (Table 4).

There was no statistical difference noticed in the distribution of the individual nor combined studied gene polymorphisms between ALL patients and controls either solely or in combinations.
Further analysis of the influence of the studied genetic polymorphisms on the clinical and laboratory features of the disease revealed that there was no statistically significant difference between AML and ALL patients harboring the wild or the variant genotypes of the studied SNPs as regards their age, gender, presenting symptoms, and clinical and laboratory data, including FAB subtypes in each group (data not shown).

\section{Discussion}

In our study, although XPD (rs13181) was not correlated to the clinicopathological characteristics of the AML subgroup, the homozygous variant genotype showed a fourfold increased risk of developing AML. XPD (rs13181) polymorphism may influence protein synthesis or affect the stability

Table 4 The frequency of XPC, XPD, and XPG polymorphisms among AML patients

\begin{tabular}{|c|c|c|c|c|c|c|c|c|c|}
\hline & & \multicolumn{2}{|c|}{ AML (32) } & \multicolumn{2}{|c|}{ Control (100) } & \multirow[t]{2}{*}{ OR } & \multirow[t]{2}{*}{$95 \% \mathrm{CI}$} & \multirow[t]{2}{*}{$p$ value } & \multirow[t]{2}{*}{ Absolute risk } \\
\hline & & Count & $\%$ & Count & $\%$ & & & & \\
\hline \multirow[t]{3}{*}{ XPD } & Wild genotype A/A & 15 & $46.9 \%$ & 66 & $66.0 \%$ & \multicolumn{4}{|c|}{ Reference } \\
\hline & Heterovariant C/A & 11 & $34.4 \%$ & 28 & $28.0 \%$ & 1.729 & $0.706-4.23$ & 0.228 & 0.0396 \\
\hline & Homovariant C/C & 6 & $18.8 \%$ & 6 & $6.0 \%$ & 4.4 & $1.245-15.556$ & 0.025 & 0.2576 \\
\hline \multirow[t]{3}{*}{$\mathrm{XPC}$} & Wild genotype $\mathrm{A} / \mathrm{A}$ & 7 & $21.9 \%$ & 22 & $22.0 \%$ & \multicolumn{4}{|c|}{ Reference } \\
\hline & Heterovariant A/C & 17 & $53.1 \%$ & 46 & $46.0 \%$ & 1.161 & $0.42-3.209$ & 0.773 & 0.0272 \\
\hline & Homovariant C/C & 8 & $25.0 \%$ & 32 & $32.0 \%$ & 0.786 & $0.249-2.483$ & 0.681 & 0.0424 \\
\hline \multirow[t]{3}{*}{ XPG } & Wild genotype $\mathrm{G} / \mathrm{G}$ & 12 & $37.5 \%$ & 46 & $46.0 \%$ & \multicolumn{4}{|c|}{ Reference } \\
\hline & Heterovariant G/C & 14 & $43.8 \%$ & 36 & $36.0 \%$ & 1.491 & $0.615-3.615$ & 0.376 & 0.0376 \\
\hline & Homovariant C/C & 6 & $18.8 \%$ & 18 & $18.0 \%$ & 1.278 & $0.416-3.921$ & 0.668 & 0.0076 \\
\hline \multicolumn{2}{|c|}{ Dual variant genotypes of XPD gene and XPC gene } & 14 & $43.8 \%$ & 25 & $25.0 \%$ & 2.333 & $1.015-5.363$ & 0.043 & 0.1166 \\
\hline \multicolumn{2}{|c|}{ Dual variant genotypes of XPD gene and XPG gene } & 11 & $34.4 \%$ & 19 & $19.0 \%$ & 2.233 & $0.922-5.406$ & 0.071 & 0.1242 \\
\hline \multicolumn{2}{|c|}{ Dual variant genotypes of XPC gene and XPG gene } & 18 & $56.2 \%$ & 40 & $40.0 \%$ & 1.929 & $0.862-4.313$ & 0.107 & 0.067 \\
\hline \multicolumn{2}{|c|}{ Triple variants of XPD, XPG, and XPC genes } & 10 & $31.2 \%$ & 13 & $13.0 \%$ & 3.042 & $1.179-7.849$ & 0.018 & 0.1924 \\
\hline
\end{tabular}


of mRNA, and it is associated with an inappropriate DNA repair capacity. This in turn might predispose to the genomic instability seen in most cancers, including AML [6].

The role of XPD (rs13181) polymorphism in AML showed controverted results, and some studies associated it with increased disease risk of AML $[2,7]$ and to bad treatment outcome of AML with shorter disease-free survival (DFS) and overall survival (OS) $[8,9]$, while others either failed to find such an association [10] or even associated XPD (rs13181) polymorphism with deceased disease risk of AML [3] and better treatment response [11].

Even in the same studied Egyptian population, El-Tokhy et al., [12] in Alexandria, Egypt, found similar distribution of XPD (rs13181) polymorphism among newly diagnosed AML patients, but they did not compare the distribution of the variant genotypes between AML patients and the controls for risk estimation. Their study showed that XPD homozygous variant genotype was associated with to the chemotherapy-induced cardiotoxicity and lower chance to achieve response to induction chemotherapy.

On the other hand, Sorour et al. [10] failed to find a statistically significant difference in the distribution of XPD (rs13181) polymorphism genotypes between Egyptian AML patients and controls. Although both results were conducted on Egyptians, the discrepancy between the studied could be attributed to enrollment of promyelocytic AML patients in their study. In our study, promyelocytic AML cases were excluded due to the different genetic, therapeutic, and prognostic features.

Dual variant genotype of XPD gene still conferred increase risk of AML even when combined with variant XPC gene alone or when combined with both XPC and XPG variant genotypes as there is a significant interaction between xeroderma pigmentosum complementation group polymorphisms in relation to leukemia risk [3].

In our study, we found no statistically significant association between XPD (rs13181) polymorphism and the risk of ALL. These results were consistent with the finding of Batar et al., [1] and Ozdemir et al., [13] in Turkey, in addition to Pakakasama et al., [14] in Thai.

On the other hand, in a meta-analysis preformed by Wang et al., [15] homozygous variant genotype of XPD (rs13181) was associated with an increased risk of ALL.

Similar to the negative association between XPD polymorphism and the risk acute lymphoid malignancy ALL, founded in our study, El-Din et al. [16] could not find an association between this polymorphism and the risk of one of the chronic lymphoid malignancies which is diffuse large B cell lymphoma (DLBCL) among Egyptian patients. These results were also reported by Smedby et al. [17] and Bahceci et al. [18].

In our study, the XPC (rs2228001) SNP was not associated with the risk of AML or ALL and did not affect the clinicopathological or laboratory data of the studied Egyptian patients. Our findings are consistent with those reported by Bănescu et al. [2] and Hernández-Boluda et al. [19].

To the contrary, Douzi et al. [3] found an association with leukemia risk and XPC homozygous variant genotype. However, subgroup analysis revealed that variant heterozygous and homozygous XPC (rs2228001) SNP genotypes were associated with a higher chronic myeloid leukemia (CML) risk when compared to AML or ALL. CML has different disease pathogenesis, genetic polymorphisms, other than NER, involved in DNA repair pathways could play a role.

Our study showed no significant association between XPG (rs17655) polymorphism and risk of development of AML or ALL. This was supported by Douzi et al. [3].

Similarly, XPG (rs17655) gene polymorphism was not to be associated with the risk of transformation of myeloproliferative neoplasms (MPN) into AML [20]. It did not affect the clinical outcome of adult AML [18] or other hematological malignancies such as Hodgkin's disease [19] and even nonhematological malignancies such as breast cancer [21].

In contrast to our study, Bănescu et al. [2] revealed that the heterozygous genotype of XPG (rs17655) gene polymorphism was associated with a twofold increased risk of developing AML.

In conclusion, determination of XPD polymorphism could be considered as molecular markers associated with susceptibility to develop AML. In addition, assessing the relation between XPD genotype and response to therapy may be a useful tool for risk stratification in Egyptian patients and thus allowing for choosing treatment modalities. Furthermore, XPD polymorphic markers may be considered as targets for new therapeutic approaches.

More extensive researches on a larger sample size are recommended to overcome the sample size which may limit the statistical power of the present study, especially for subgroup analyses as well as follow-up of patients to collect relevant sufficient data.

\section{Compliance with ethical standards}

Funding Fund was received from the Faculty of Medicine, Cairo University.

Conflict of interest The authors declare that they have no conflict of interest.

Ethical approval All procedures performed in studies involving human participants were in accordance with the ethical standards of the institutional and/or national research committee and with the 1964 Helsinki Declaration and its later amendments or comparable ethical standards.

Informed consent Informed consent was obtained from all individual participants included in the study. 


\section{References}

1. Batar B, Güven M, Bariş S, Celkan T, Yildiz I (2009) DNA repair gene XPD and XRCC1 polymorphisms and the risk of childhood acute lymphoblastic leukemia. Leuk Res 33(6):759-763

2. Bănescu C, Iancu M, Trifa AP, Dobreanu M, Moldovan VG, Duicu C, Tripon F, Crauciuc A, Skypnyk C, Bogliş A, Lazar E (2016) Influence of XPC, XPD, XPF, and XPG gene polymorphisms on the risk and the outcome of acute myeloid leukemia in a Romanian population. Tumour Biol 37(7):9357-9366

3. Douzi K, Ouerhani S, Menif S, Safra I, Abbes S (2015) Polymorphisms in XPC, XPD and XPG DNA repair genes and leukemia risk in a Tunisian population. Leuk Lymphoma 56(6): 1856-1862

4. Monroy CM, Cortes AC, Lopez M, Rourke E, Etzel CJ, Younes A, Strom SS, El-Zein R (2011) Hodgkin lymphoma risk: role of genetic polymorphisms and gene-gene interactions in DNA repair pathways. Mol Carcinog 50(11):825-834

5. Herzog CM, Dey S, Hablas A, Khaled HM, Seifeldin IA, Ramadan M, El-Hamzawy H, Wilson ML, Soliman AS (2012) Geographic distribution of hematopoietic cancers in the Nile delta of Egypt. Ann Oncol 23(10):2748-2755

6. Liu D, Wu D, Li H, Dong M (2014) The effect of XPD/ERCC2 Lys751Gln polymorphism on acute leukemia risk: a systematic review and meta-analysis. Gene 538(2):209-216

7. Shi JY, Ren ZH, Jiao B, Xiao R, Yun HY, Chen B, Zhao WL, Zhu Q, Chen Z, Chen SJ (2011) Genetic variations of DNA repair genes and their prognostic significance in patients with acute myeloid leukemia. Int J Cancer 128(1):233-238

8. Allan JM, Smith AG, Wheatley K, Hills RK, Travis LB, Hill DA, Swirsky DM, Morgan GJ, Wild CP (2004) Genetic variation in XPD predicts treatment outcome and risk of acute myeloid leukemia following chemotherapy. Blood 104(13):3872-3877

9. Monzo M, Brunet S, Urbano-Ispizua A, Navarro A, Perea G, Esteve J, Artells R, Granell M, Berlanga J, Ribera JM, Bueno J, Llorente A, Guardia R, Tormo M, Torres P, Nomdedéu JF, Montserrat E, Sierra J, CETLAM (2006) Genomic polymorphisms provide prognostic information in intermediate-risk acute myeloblastic leukemia. Blood 107(12):4871-4879

10. Sorour A, Ayad MW, Kassem H (2013) The genotype distribution of the XRCC1, XRCC3, and XPD DNA repair genes and their role for the development of acute myeloblastic leukemia. Genet Test Mol Biomarkers 17(3):195-201

11. Kuptsova-Clarkson N, Ambrosone CB, Weiss J, Baer MR, Sucheston LE, Zirpoli G, Kopecky KJ, Ford L, Blanco J, Wetzler M, Moysich KB (2010) XPD DNA nucleotide excision repair gene polymorphisms associated with DNA repair deficiency predict better treatment outcomes in secondary acute myeloid leukemia. Int $\mathbf{J}$ Mol Epidemiol Genet 1:278-294
12. El-Tokhy MA, Hussein NA, Bedewy AM, Barakat MR (2014) XPD gene polymorphisms and the effects of induction chemotherapy in cytogenetically normal de novo acute myeloid leukemia patients. Hematology 19(7):397-403

13. Ozdemir N, Celkan T, Barıs S, Batar B, Güven M (2012) DNA repair gene XPD and XRCC1 polymorphisms and the risk of febrile neutropenia and mucositis in children with leukemia and lymphoma. Leuk Res 36(5):565-569

14. Pakakasama S, Sirirat T, Kanchanachumpol S, Udomsubpayakul U, Mahasirimongkol S, Kitpoka P, Thithapandha A, Hongeng S (2007) Genetic polymorphisms and haplotypes of DNA repair genes in childhood acute lymphoblastic leukemia. Pediatr Blood Cancer 48(1):16-20

15. Wang F, Chang D, Hu FL, Sui H, Han B, Li DD, Zhao YS (2008) DNA repair gene XPD polymorphisms and cancer risk: a metaanalysis based on 56 case-control studies. Cancer Epidemiol Biomark Prev 17(3):507-517

16. El-Din MA, Khorshied MM, El-Saadany ZA, El-Banna MA, Reda Khorshid OM (2013) Excision repair cross complementing group 2/Xeroderma pigmentousm complementation group D(ERCC2/ XPD) genetic variations and susceptibility to diffuse large B cell lymphoma in Egypt. Int J Hematol 98(6):681-686

17. Smedby KE, Lindgren CM, Hjalgrim H, Humphreys K, Schöllkopf C, Chang ET, Roos G, Ryder LP, Falk KI, Palmgren J, Kere J, Melbye M, Glimelius B, Adami HO (2006) Variation in DNA repair genes ERCC2, XRCC1, and XRCC3 and risk of follicular lymphoma. Cancer Epidemiol Biomark Prev 15(2):258-265

18. Bahceci A, Paydas S, Tanriverdi K, Ergin M, Seydaoglu G, Ucar G (2015) DNA repair gene polymorphisms in B cell non-Hodgkin's lymphoma. Tumour Biol 36(3):2155-2161

19. El-Zein R, Monroy CM, Etzel CJ, Cortes AC, Xing Y, Collier AL, Strom SS (2009) Genetic polymorphisms in DNA repair genes as modulators of Hodgkin disease risk. Cancer 115(8):1651-1659

20. Hernández-Boluda JC, Pereira A, Cervantes F, Alvarez-Larrán A, Collado M, Such E, Arilla MJ, Boqué C, Xicoy B, Maffioli M, Bellosillo B, Marugán I, Amat P, Besses C, Guillem V (2012) A polymorphism in the XPD gene predisposes to leukemic transformation and new nonmyeloid malignanciesin essential thrombocythemia and polycythemia vera. Blood 119(22):52215228

21. Ding DP, He XF, Zhang Y (2001) Lack of association between XPG Asp1104His and XPF Arg415Gln polymorphism and breast cancer risk: a meta-analysis of case-control studies. Breast Cancer Res Treat 129(1):203-209

In the current study, the polymorphisms of XPD, XPC, and XPG were studied by PCR-RFLP in 50 acute leukemia patients and compared to 100 normal control volunteers. 